Zakład Geologii Morza, Centrum Dydaktyczno-Badawcze Nauk Przyrodniczych, Instytut Nauk o Morzu, Wydział Nauk o Ziemi, Uniwersytet Szczeciński

\title{
Najcenniejsze naukowo zbiory Muzeum Geologicznego Uniwersytetu Szczecińskiego
}

\author{
ABSTRACT \\ The most valuable scientific collection at the Geological Museum \\ of Szczecin University
}

The Geological Museum of the University of Szczecin was founded in 1994. For 24 years the Museum has changed its location several times and last year it finally moved to the Natural Sciences Education and Research Centre of the University of Szczecin. The Museum's collection holds over 4320 exhibits, including such specimens as minerals, rocks, fossils, meteorites, and sand samples. The most valuable scientific collections are: the specimens of one of the oldest rocks in the world, originated from the Isua Greenstone Belt, Oligocene sand concretions, the so-called Szczecin balls (Germ. Stettiner Kugeln), the collection of minerals with the fluorescence phenomenon on display, and the collection of sand samples from various beaches and deserts. The Museum serves its primary educational function and organises many events, such as geological workshops, trainings, and others.

Keywords: geology, geological museum, geological collection, Earth sciences

Słowa kluczowe: geologia, muzeum geologiczne, kolekcja geologiczna, nauki o Ziemi 


\section{Krótka historia Muzeum Geologicznego Uniwersytetu Szczecińskiego}

Muzeum Geologiczne Uniwersytetu Szczecińskiego to jedyna stale otwarta uczelniana placówka muzealna na mapie Szczecina ${ }^{1}$. Muzeum zostało założone w 1994 roku na ówczesnym Wydziale Nauk Przyrodniczych, a jego spiritus movens był prof. dr hab. Stanisław Musielak, który funkcję pierwszego kierownika placówki powierzył dr. Stanisławowi Piotrowskiemu. Pierwotnie miało ono formę niewielkiej ekspozycji na korytarzach WNP przy ulicy Felczaka. W trakcie budowania kolekcji oraz rozwoju muzeum kilkukrotnie zmieniało ono lokalizację. Najdłużej zagościło w Rektoracie Uniwersytetu Szczecińskiego, gdzie funkcjonowało do roku 2006. W tych latach kierownikiem był dr hab. Bernard Cedro. Od 2008 roku muzeum mieści się w campusie powstałego w tym czasie Wydziału Nauk o Ziemi przy ulicy Mickiewicza 16-18. Pierwotnie zajmowało pomieszczenia w piwnicy budynku, ale w 2016 roku po wybudowaniu Centrum Dydaktyczno-Badawczego Nauk Przyrodniczych Uniwersytetu Szczecińskiego muzeum zyskało nowe pomieszczenia i otworzyło Salę Interaktywnej Edukacji Geośrodowiskowej (il. 1), dzieląc pierwsze piętro z wypożyczalnią Biblioteki Głównej US. Uroczyste (ponowne) otwarcie muzeum w nowej siedzibie nastąpiło 23 marca 2017 roku i zostało zauważone nie tylko przez czasopisma związane z Uniwersytetem Szczecińskim², ale także przez periodyk geologiczny o zasięgu ogólnopolskim³ ${ }^{3}$.

\section{Aktualna dzialalność}

Dzięki dofinansowaniu otrzymanemu z Wojewódzkiego Funduszu Ochrony Środowiska i Gospodarki Wodnej w Szczecinie w 2016 roku możliwa była realizacja projektu „Doposażenie Sali Interaktywnej Edukacji Geośrodowiskowej Centrum Dydaktyczno-Badawczego Nauk Przyrodniczych Uniwersytetu Szczecińskiego dla celów edukacyjnych i dydaktycznych". Wsparcie finansowe opiewało na blisko 130 tys. zł i przeznaczone było na zakup nowych okazów mineralogicznych i paleontologicznych, zaprojektowanie i wykonanie prototypowych stanowisk interaktywnych gry Surowce Polski (il. 2), cyfrowego fotoplastykonu, gablot z minerałami wykazującymi zjawisko fluorescencji, stworzenie wystawy „Historia geologiczna Regionu Bałtyckiego” (il. 3) oraz zakupu wielu pomocy dydaktycznych (np. zestawów Skali Mohsa, modeli krystalograficznych). Obecnie kierownikiem muzeum jest dr Robert Woziński, a kustoszem dr Dominik Zawadzki. Jednym z głównych zadań Muzeum Geologicznego jest prowadzenie szeroko pojętej edukacji geośrodowiskowej, w dużej mierze nastawionej na geologię, paleontologię oraz współczesne organizmy morskie. Główną grupę odwiedzających placówkę

${ }^{1}$ Muzeum przy Zakładzie Historii Medycyny Pomorskiego Uniwersytetu Medycznego ma charakter zamknięty.

${ }^{2}$ D. Zawadzki, E.B. Nowak, Cały świat w Muzeum Geologicznym US, „Przegląd Uniwersytecki” 2017, s. 1-3.

${ }^{3}$ W. Mizerski, Muzeum Geologiczne na Wydziale Nauk o Ziemi Uniwersytetu Szczecińskiego, „Przegląd Geologiczny” 2017, nr 65 (8). 


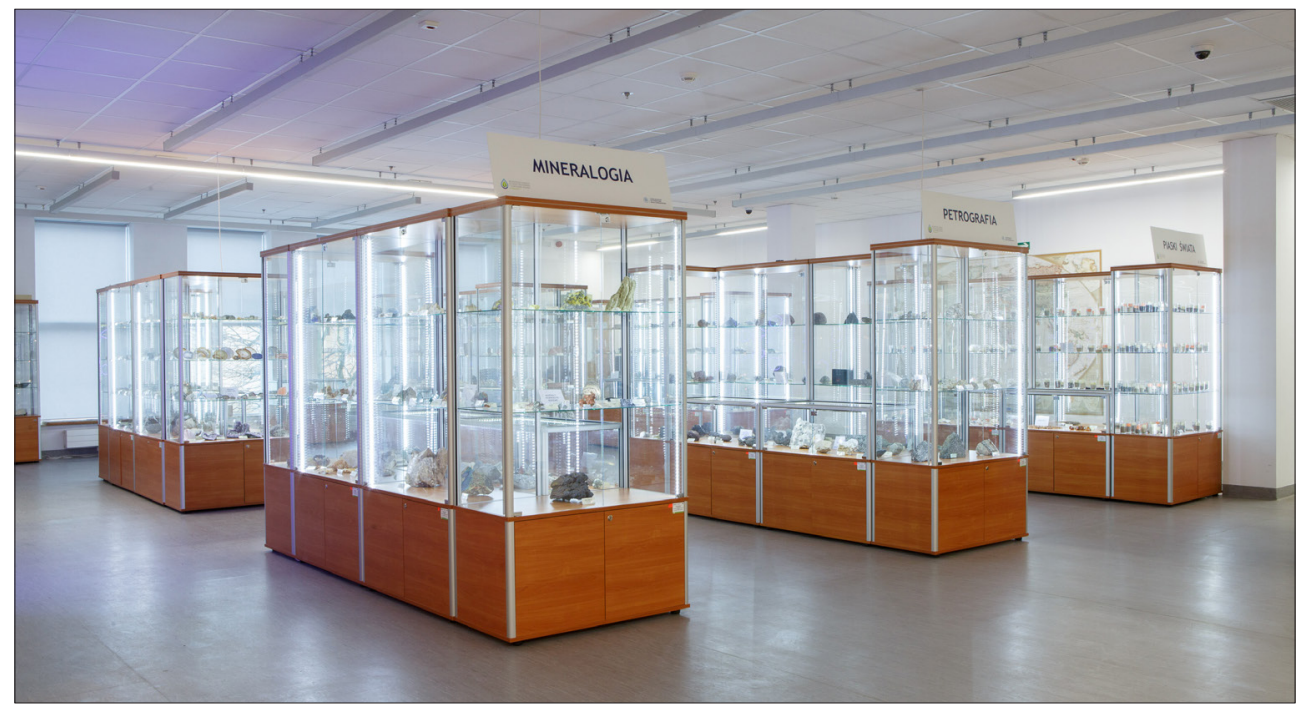

II. 1. Sala Interaktywnej Edukacji Geośrodowiskowej Muzeum Geologicznego, część systematyczna. W poszczególnych „wyspach” gablot znajdują się usystematyzowane pod względem chemicznym minerały oraz skały w podziale na trzy typy skał: magmowe, osadowe i metamorficznej. Fot. F. Kacalski

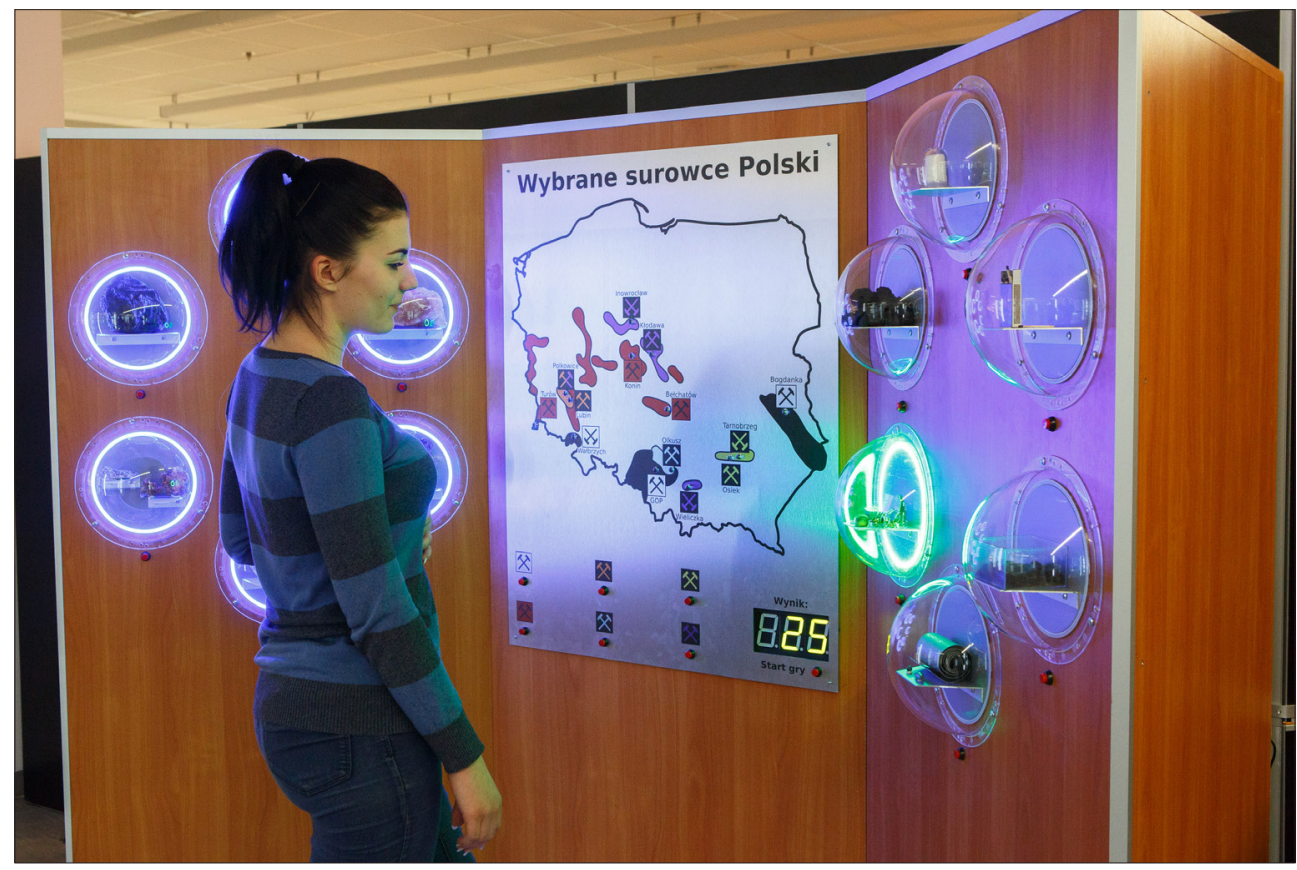

Il. 2. Interaktywna gra Surowce Polski. Stanowisko jest prototypem wykonanym w ramach dofinansowania Wojewódzkiego Funduszu Ochrony Środowiska i Gospodarki Wodnej w Szczecinie. Fot. F. Kacalski 


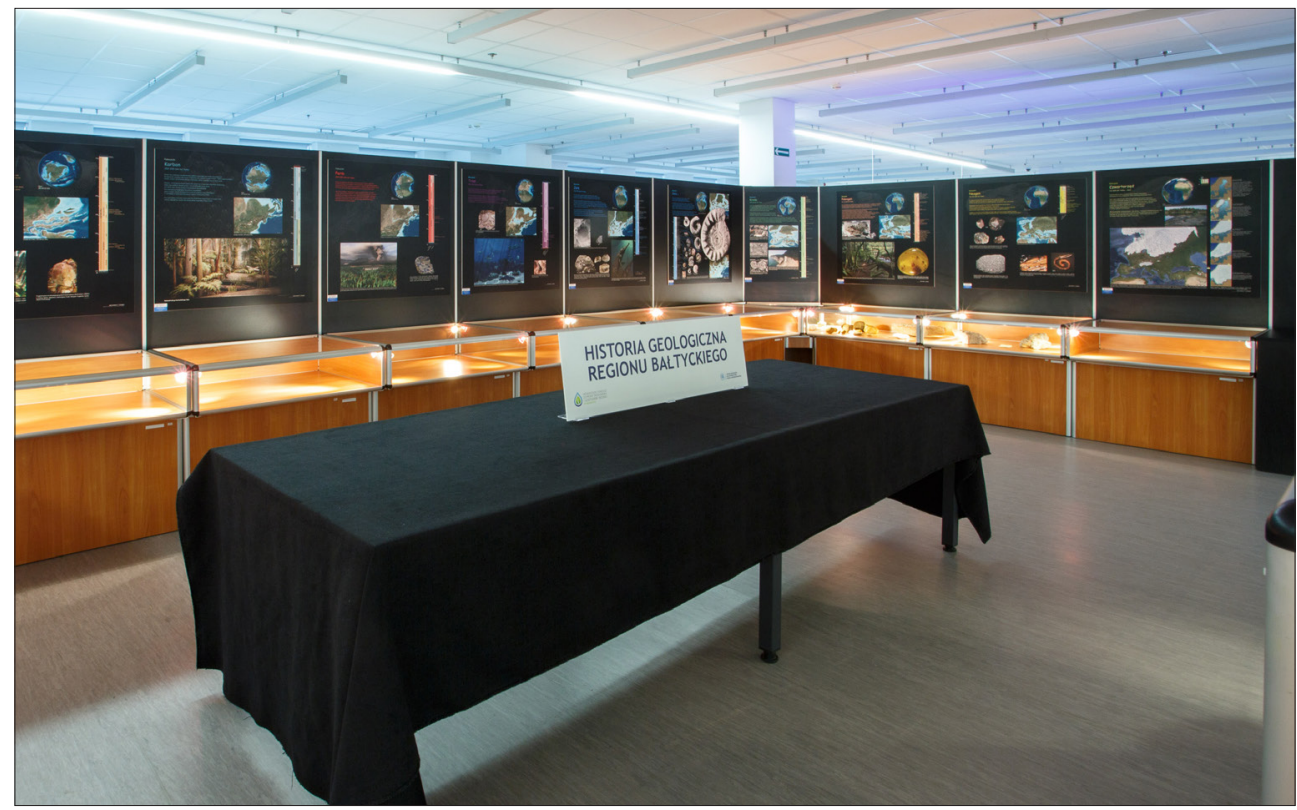

Il. 3. Ekspozycja „Historia geologiczna Regionu Bałtyckiego”. W płaskich gablotach pod poszczególnymi planszami obrazującymi kolejne okresy znajdują się okazy skał i skamieniałości charakterystyczne dla danego okresu geologicznego. Fot. F. Kacalski

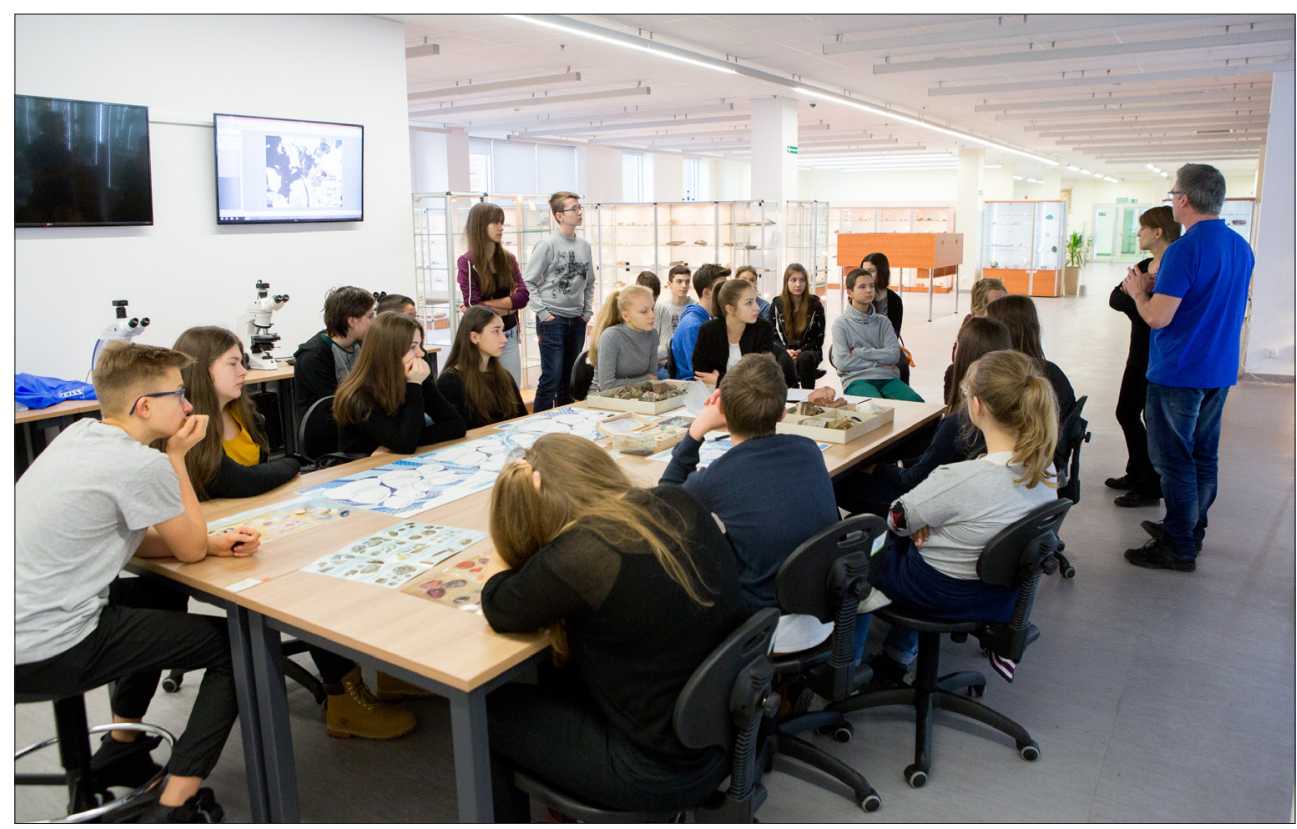

Il. 4. Warsztaty edukacyjne dla młodzieży szkolnej prowadzone przez kierownika Muzeum Geologicznego US dr. Roberta Wozińskiego. Fot. F. Kacalski 
stanowią dzieci i młodzież szkół podstawowych i średnich w zorganizowanych grupach (il. 4). W zależności od wieku, zainteresowań i oczekiwań młodzież uczestniczy w jednym z kilku warsztatów pt.: „Uwiecznij Amonita” (dedykowanych uczestnikom w wieku 7-11 lat), „Fascynujący świat minerałów” (12-16 lat). Najmłodsi zwiedzający biorą udział w konkursie plastycznym pt. „Narysuj, jaki dinozaur wykluje się z jaja”. W muzeum prowadzone są również warsztaty metodyczne dla nauczycieli geografii oraz przyrody „Z geologią za pan brat - czyli jak ciekawie i bez obaw uczyć dzieci i młodzież o fascynującym świecie minerałów, skał oraz skamieniałości”. Placówka aktywnie bierze udział w Europejskiej Nocy Muzeów, Zachodniopomorskim Festiwalu Nauki, Tygodniu Ziemi oraz Dni Otwartych Funduszy Europejskich.

\section{Zbiory}

Już od samego początku istnienia, dwóch pierwszych kierowników muzeum rozpoczęło mozolną pracę polegającą na budowaniu kolekcji geologicznej. Podstawowym ich celem było zebranie jak największej liczby różnorodnych okazów, które stanowiłyby systematyczny zbiór najważniejszych minerałów, skał i skamieniałości. Kolekcje geologiczne są specyficznym typem kolekcji muzealnych, które w znacznej mierze można pozyskiwać samemu, jeżdżąc i zbierając okazy minerałów, skał i skamieniałości w różnego rodzaju sztucznych (kopalnie, kamieniołomy) i naturalnych odsłonięciach geologicznych (obszary górskie, wybrzeże morskie). Dobre i bardzo dobre kolekcje geologiczne buduje się dziesiątkami lat i jest w to zaangażowanych kilka pokoleń geologów i pracowników tych placówek. Do najbogatszych w Polsce należą obecnie Muzeum Geologiczne Państwowego Instytutu Geologicznego - Państwowego Instytutu Badawczego (500 tys. okazów), Muzeum Geologiczne im. Stanisława Józefa Thugutta na Wydziale Geologii Uniwersytetu Warszawskiego (ponad 28 tys. numerów katalogowych w tym ok. 1 tys. holotypów), Muzeum Geologiczne im. Henryka Teisseyre Uniwersytetu Wrocławskiego (ponad 20 tys. okazów). Muzeum geologiczne w mieście takim jak Szczecin, które nigdy nie miało silnej tradycji geologicznej ani górniczej, całą swoją kolekcję musiało budować od podstaw. Dzięki wytężonej pracy, przychylności władz uniwersyteckich, niezliczonej rzeszy wolontariuszy i osób zasilających swoimi okazami kolekcję muzealną w 2018 roku muzeum może pochwalić się:

- 826 numerami katalogowymi minerałów (sygnatury M) (il. I-IV),

- 1172 numerami skał (P) (il. V),

- 1130 numerami skamieniałości (S) (il. VI).

- 23 sztukami konkrecji polimetalicznych z Oceanu Spokojnego (K),

- 13 meteorytami (MK),

- 406 konkrecjami, tzw. kulami szczecińskimi (KS),

- 754 próbkami piasków plaż i pustyń świata (P) (jest to największa tego typu kolekcja muzealna w Polsce).

Powyższe zbiory muzealne pochodzą z kilku źródeł. Podstawowym z nich jest samodzielne gromadzenie okazów przez pracowników muzeum podczas wyżej wspomnianych 
tzw. wyjazdów w teren. Duża część kolekcji to dary na rzecz muzeum. Na uwagę zasługuje kilkanaście wspaniałych okazów przekazanych w 2017 roku przez prof. dr. hab. Krzysztofa Kurzydłowskiego z Politechniki Warszawskiej czy gromadzona od początku XXI wieku kolekcja oligocenu ofiarowana przez pana Walerego Kościuszkiewicza, poszukiwacza skamieniałości w podszczecińskich lasach i odkrywkach. Jeszcze innym sposobem wzbogacenia o nowe okazy są zakupy na giełdach mineralogicznych czy portalach transakcyjnych oferujących eksponaty geologiczne. Takie zakupy są dokonywane sporadycznie przy okazji posiadania na ten cel funduszy w ramach prowadzonych projektów czy dofinansowań. Poza własnymi zbiorami w muzeum wyeksponowano wiele okazów wypożyczonych z prywatnych kolekcji. Bardzo dużą kolekcję wspaniałych okazów mineralogicznych wypożyczyła do Muzeum Beata Zielińska, która współpracuje z placówką niemalże od samych jej początków. Ciekawe zbiory prezentują również pracownicy Wydziału Nauk o Ziemi: dr hab. Bernard Cedro, dr hab. Jakub Witkowski, mgr Łukasz Maciąg czy niżej podpisany.

Pomysłodawcą kolekcjonowania „piasków plaż świata” był wspomniany powyżej prof. dr hab. Stanisław Musielak, jeden z twórców szczecińskiej szkoły geograficznej. W pierwszych latach działalności muzeum uwrażliwił on pracowników wydziału i osoby wspierające, aby z każdej wyprawy naukowej oraz prywatnego wyjazdu na wybrzeże morskie przywozili oni próbkę piasku. Obecnie zbiór obejmuje piaski plażowe i pustynne. Dzięki temu muzeum zyskało oryginalną kolekcję, która jest już produktem eksportowym (część kolekcji wypożyczona była w 2017 roku do Pracowni Muzeum Ziemi Wydziału Nauk Geograficznych i Geologicznych, Uniwersytetu im. Adama Mickiewicza w Poznaniu oraz przekazana do Muzeum Geologicznego PIG-PIB).

Dzięki wyeksponowaniu kilkuset próbek piasków z różnych lokalizacji na świecie, zwiedzający uświadamiają sobie, czym są piasek i żwir, jak różnorodne mogą być utwory plażowe pod względem barwy, składu mineralnego, rozmiaru ziaren, kształtu obtoczenia czy wysortowania. Muzeum posiada w kolekcji zielony piasek z Hawajów (jedyna tego typu plaża na świecie), czarne z wysp wulkanicznych (Islandii, Wysp Kanaryjskich, Gwadelupy), czerwone (Indii, Australii czy Irk asz-Szabbi w Maroku), śnieżnobiałe piaski koralowe (z Zanzibaru, Martyniki), przyciągane przez magnes osady z wybrzeża Bałtyku czy zbudowane w dużej mierze z szafirów piaski ze Sri Lanki (il. VII-IX).

\section{Skały formacji Isua}

Jednymi z najcenniejszych pod względem naukowym okazów są skały z grenlandzkiej formacji Isua, które muzeum otrzymało w darze od niemieckiego profesora Manfreda Schidlowskiego, urodzonego 13 listopada 1931 roku w Szczecinie, gdzie spędził dzieciństwo. Z końcem drugiej wojny światowej jego rodzina opuściła Szczecin i osiedliła się w Greifswaldzie. Schidlowski w latach 1952-1955 studiował na Uniwersytecie Humboldtów w Berlinie, a następnie w Wolnym Uniwersytecie Berlińskim, gdzie w 1961 roku został doktorem geologii. Wkrótce potem rozpoczął badania w Republice Południowej Afryki, gdzie zainteresował się najwcześniejszymi dziejami Ziemi. W roku 1963 wrócił 
do Niemiec, gdzie zaczął badania nad zgromadzonym w Afryce materiałem. W latach 1965-1967 pracował na Uniwersytecie Jerzego Augusta w Getyndze, a habilitację ukończył na Uniwersytecie Ruprechta i Karola w Heidelbergu. Od 1969 roku związany był z Towarzystwem Wspierania Nauki im. Maxa Plancka na Wydziale Chemii w Moguncji (Max-Planck-Institut für Chemie in Mainz), gdzie był profesorem. Można go nazwaćjednym z największych autorytetów w dziedzinie badań nad wczesnymi etapami rozwoju atmosfery ziemskiej oraz zapisem izotopowym najstarszych śladów życia na Ziemi. W 2005 roku profesor Schidlowski przekazał Uniwersytetowi Szczecińskiemu znaczą część swojej prywatnej biblioteki, a także bezcenne naukowo okazy skał pochodzących z Grenlandii i RPA. Profesor odwiedził Szczecin przy okazji konferencji naukowej Geopomerania. Zmarł 3 października 2012 roku w Altusried ${ }^{4}$.

Skały archaicznej formacji zieleńcowej Isua, pochodzące z południowo-zachodniej Grenlandii, to jedne z najstarszych skał na Ziemi. Ich wiek został oznaczony metodami izotopowymi (metoda $\mathrm{Rb}-\mathrm{Sr}$ ) na 3,7-3,8 mld lat. Od lat 70. XX wieku są one szeroko opisywane w literaturze 5 . Są to głównie zmetamorfizowane skały pochodzenia wulkanicznego i osadowego (il. X), w których znaleziono nie tylko najstarsze ślady życia w postaci grafitu (zmetamorfizowanego pierwotnego węgla), ale także w ostatnich latach najstarsze stromatolity (formacje skalne powstające przy udziale sinic-Cyanobacteria) ${ }^{6}$.

\section{Kule szczecińskie (Stettiner Kugeln)}

Inną, bardzo interesującą kolekcją pochodzącą tym razem z najbliższego regionu są tzw. kule szczecińskie. Są to konkrecje piaskowców wapienno-żelazistych często o idealnie kulistych kształtach o wielkości od kilku do kilkunastu centymetrów. Konkrecje to agregaty mineralne, które powstają w wyniku systematycznego narastania różnych minerałów wokół jądra. Może być to fragment organiczny (ząb rekina, skorupka małża, ślimaka), okruch skalny lub ziarno piasku. Konkrecje mogą mieć wielkość od kilku milimetrów do kilkudziesięciu centymetrów, w ekstremalnych przypadkach powyżej metra. Znane są konkrecje o różnym składzie mineralnym i różnorodnej genezie (konkrecje septariowe, polimetaliczne, fosforanowe). Szczecińskie konkrecje w swoim wnętrzu zawierają bogatą fauną morską, której wiek datuje się na oligocen (rupel, który

${ }^{4}$ Informacje na podstawie https://de.wikipedia.org/wiki/Manfred_Schidlowski[dostęp:27.06.2017].

5 Vide m.in. S. Moorbath, R.K. O'Nions, R.J. Pankhurst, Early Archaean age for the Isua iron formation, West Greenland, „Nature” 1973, nr 245, s. 138-139; M. Schidlowski, P.W.U. Appel, R. Eichmann, C.E. Junge, Carbon isotope geochemistry of the 3.7x109-yr-old Isua sediments, West Greenland: implications for the Archaean carbon and oxygen cycles, „Geochim. Cosmochim. Acta” 1979, 43, s. 189-199; A.P. Nutman, V.R. McGregor, C.R.L. Friend, V.C. Bennett, P.D. Kinny, The Itsaq Gneiss Complex of southern West Greenland; the world's most extensive record of early crustal evolution (3900-3600 Ma), „Precambrian Research” 1996, nr 78, s. 1-39.

${ }^{6}$ A.P. Nutman, V.C. Bennett, C.R.L. Friend, M.J. van Kranendonk, A. Chivas, Rapid emergence of life shown by discovery of 3,700-million-year-old microbial structures, „Nature” 2016, $\mathrm{nr}$ 537, s. 535-538. 
trwał od 33,9 do 27,82 mln lat temu) ${ }^{7}$. Transgresja morska objęła w tym czasie cały teren Pomorza Zachodniego, jak również dużej części Polski, wystąpiły więc dogodne warunki do tworzenia się takich form. Twory znajdowane w podszczecińskich lasach nie zawsze są idealnie kuliste. Często trafiają się nieregularne soczewy, większe bryły, a także nieregularne formy o płaskim kształcie z licznymi szczątkami organicznymi, takimi jak: Pecten sp., Panopea heberti, ślimaki Signatica hantoniensis, Galeodea depressa. Podrzędnie występują szczątki należące do innych taksonów: łódkonogów, mszywiołów, ryb (łuski, kości, otolity) czy rekinów (zęby) ${ }^{8}$ (il. XI-XIII). Na szczególną uwagę zasługuje typowy dla okolic Szczecina gatunek małża Pecten stettinensis ${ }^{9}$.

Kule szczecińskie znajdowane były w okolicach dzisiejszego miasta zapewne dużo wcześniej niż pierwsze szczegółowo opisane okazy, jednakże wzmianki w czasopismach naukowych pojawiły się na przełomie XIX i XX wieku. Wilhelm Deecke w swoim dziele Geologie von Pommern z 1907 roku opisał Stettiner Kugeln w rozdziale poświęconym oligocenowi ${ }^{10}$. W latach 20 . i 30. XX wieku w wyniku prowadzonych na terenie Szczecina i okolic działań górniczych (głównie pozyskanie iłów) stwierdzono wiele dobrze zachowanych Stettiner Kugeln. Część skamieniałości, która występuje w zgromadzonych konkrecjach, została zidentyfikowana do poziomu nazwy rodzajowej, a niektóre do gatunkowej. Na niektórych okazach widnieją numery inwentarzowe nadane przez znalazcę. Część z nich umieszczona jest centralnie na fragmentach skamieniałości, co jest metodą dziś niepraktykowaną, obniżającą wartość eksponatu. Zbiory były gromadzone w istniejącym od 1913 roku Das Städtische Museum Stettin, a po drugiej wojnie światowej pozostały w Szczecinie, zasilając kolekcję nowo powstałego Muzeum Narodowego. W magazynach placówki pozostały do początków XXI wieku, kiedy to na zasadzie umowy długoterminowego wypożyczenia trafiły do $\mathrm{Mu}-$ zeum Geologicznego, gdzie je skatalogowano i sfotografowano. Niezwykle cennymi historycznymi elementami wyżej wspomnianej kolekcji są oprócz samych kul szczecińskich wykonane odręcznie etykiety, które zachowały się wraz z okazami. Znajdują się na nich: nazwa gatunkowa (lub rodzajowa) skamieniałości, jej wiek (oligocen), rok i miejsce odnalezienia. Na niektórych etykietach widnieje również imię i nazwisko znalazcy (il. 5).

Z kulami szczecińskimi wiąże się również ciekawa historia mistyfikacji polegającej na opisaniu domniemanego znaleziska skamieniałości motyla w kuli szczecińskiej ${ }^{11}$. Był to prawie kompletnie zachowany okaz motyla wraz z dobrze widoczną głową, skrzydłami i nogami znaleziony w kopalni gliny w Stolzenhagen (dzisiejszy Stołczyn, jedna z północnych dzielnic Szczecina). Co ciekawe, znalezisko to było komentowane i cytowane

7 The International Commission on Stratigraphy, 2017, http://www.stratigraphy.org/ICSchart/ ChronostratChart2017-02.pdf [dostęp: 27.06.2017].

${ }^{8}$ P. Sztajner, Nagromadzenia fauny w piaskach szczecińskich (oligocen, rupel), poster, 2008.

9 M. Reich, „Pecten” stettinensis v. Koenen, 1868 (Molluska: Bivalvia) aus einer „Stettiner Kugel” (Oligozän) „Geschiebekunde aktuell” 2002, nr 18 (1), s. 1-2.

10 W. Deecke, Geologie von Pommern, Berlin 1907.

${ }^{11}$ G. Wangrin, Tagfalter-Versteinerung in einer „Stettiner Kugel”, „Entomologische Zeitschrift.” 1939, nr 53 (24), s. 192-194. 


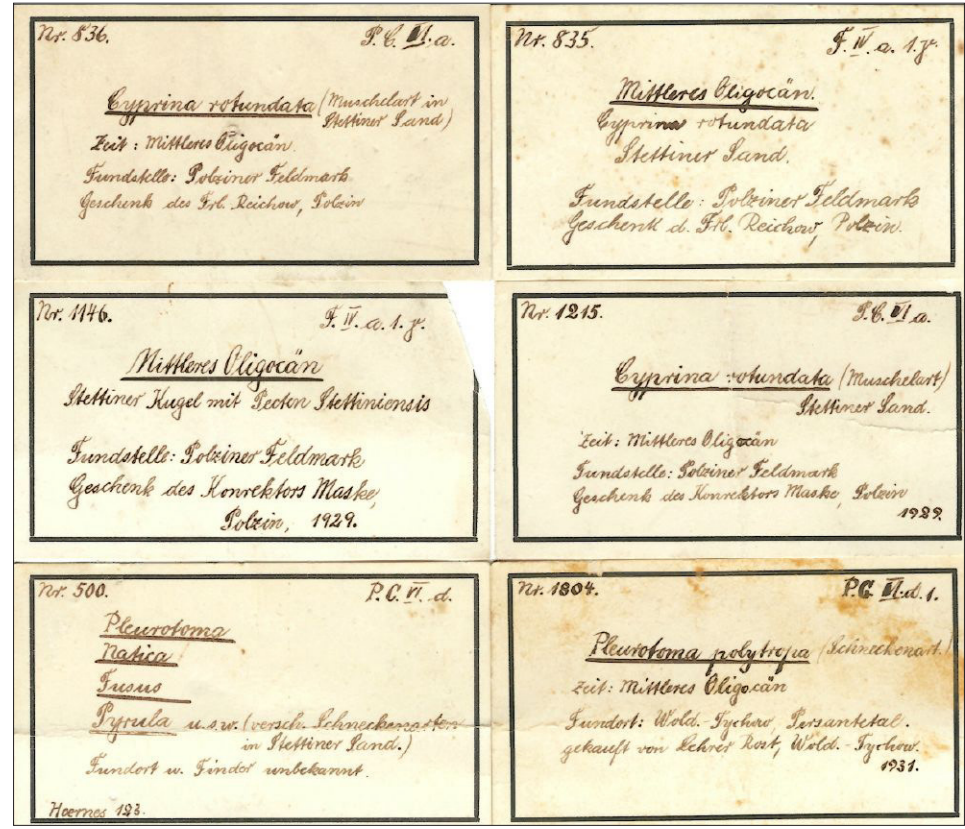

Il. 5. Historyczne etykietki kul szczecińskich pochodzące z lat 20. i 30. XX wieku zgromadzone w Das Städtische Museum

w literaturze poświęconej ewolucji motyli ${ }^{12}$. Dopiero w 2015 roku po przypadkowym odnalezieniu okazu i jego dokładnej analizie okazało się, że jest to gipsowy odcisk współczesnego motyla umieszczony w jednej połówce kuli szczecińskiej (Wangrin utrzymywał, że druga połowa konkrecji została zniszczona podczas rozbijania kuli, co wydaje się bardzo prawdopodobne $\left.{ }^{13}\right)$.

\section{Minerały fluorescencyjne}

Do atrakcji Muzeum Geologicznego US należy również zaliczyć kolekcję minerałów wykazujących zjawisko fluorescencji, wyeksponowanych w specjalnie do tego celu zaprojektowanej i wykonanej prototypowej gablocie, świecącej w trzech różnych zakresach promieniowania ultrafioletowego (UV-A, UV-B, UV-C). Zjawisko fluorescencji minerałów jest jednym z rodzajów luminescencji, która polega na absorbowaniu pewnej części energii, a następnie emitowaniu jej w postaci promieniowania widzialnego. Występuje ono pod wpływem naświetlania niektórych minerałów (zawierających w sieci

12 O. Shields, Fossil Butterflies and the evolution of Lepidoptera, „Journal of Research on the Lepidoptera" 1976, nr 15 (3), s. 132-143.

13 J. Ansorge, Günther Wangrins Tagfalter-Versteinerung in einer Stettiner Kugel-die Geschichte einer Fälschung, „Geschiebekunde aktuell” 2015, nr 31 (4), s. 98-103. 
krystalicznej atomy pierwiastków zwanych aktywatorami) światłem ultrafioletowym. Przykładami takich minerałów są niektóre fluoryty (z wielu lokalizacji na świecie najbardziej znaną z nich jest Rogerley Mine w Anglii), gipsy (ciekawe zjawisko tzw. klepsydry wykazują gipsy z Dobrzynia nad Wisłą), rubiny, cynkit, cerusyt, celestyn, a także wiele minerałów promieniotwórczych (uranocircyt). Większość minerałów najintensywniej wykazuje fluorescencję podczas działania światła UV-A (promieniowanie elektromagnetyczne o długość fali 315-380 nm), kiedy to zmieniają one barwę na inną niż podczas oświetlania zwykłym światłem widzialnym żarówki. Zjawisko to jest chwilowe i zanika wraz z zaprzestaniem oświetlania minerału światłem ultrafioletowym. Pozostałe pasma, UV-B (długość fali 280-315 nm) i UV-C (długość fali 100-280 nm), pobudzają minerały w mniejszym stopniu.

Obecnie w Muzeum w specjalnie przystosowanym do tego celu pomieszczeniu, w którym panuje półmrok, a ściany pokoju pomalowano na ciemny kolor, znajduje się gablota, z kilkunastoma minerałami wykazującymi fluorescencję (il. XIV, XV). Zwiedzający sam ustala, którą długość światła ultrafioletowego lub zwykłej świetlówki skierować na okazy. Zwykle ten punkt wizyt w muzeum cieszy się największą popularnością. Zwiedzający bez względu na wiek są pod dużym wrażeniem tej cechy minerałów.

W 2017 roku Salę Interaktywnej Edukacji Geośrodowiskowej Muzeum Geologicznego odwiedziło ponad 4 tys. osób. W 2017 roku przeprowadzono ponad 140 warsztatów i lekcji geologii dla dzieci i młodzieży na wszystkich szczeblach edukacji. Podczas spotkań, warsztatów i międzynarodowych konferencji zwiedzającymi były pojedyncze osoby z całego świata. Prowadzący warsztaty kierownik muzeum, kustosz, jak również wolontariuszki i wolontariusze wielokrotnie usłyszeli słowa uznania za włożoną pracę i pasję, z jaką działają na rzecz placówki.

\section{Bibliografia}

Ansorge J., Günther Wangrins Tagfalter-Versteinerung in einer Stettiner Kugel - die Geschichte einer Fälschung, „Geschiebekunde aktuell” 2015, nr 31 (4).

Deecke W., Geologie von Pommern, Berlin 1907.

https://de.wikipedia.org/wiki/Manfred_Schidlowski [dostęp: 27.06.2017].

Mizerski W., Muzeum Geologiczne ña Wydziale Nauk o Ziemi Uniwersytetu Szczecińskiego, „Przegląd Geologiczny” 2017, nr 65 (8).

Moorbath S., O'Nions R.K., Pankhurst R.J., Early Archaean age for the Isua iron formation, West Greenland, „Nature” 1973, nr 245.

Nutman A.P., Bennett V.C., Friend C.R.L., van Kranendonk M.J., Chivas A., Rapid emergence of life shown by discovery of 3,700-million-year-old microbial structures, „Nature” 2016, nr 537.

Nutman A.P., McGregor V.R., Friend C.R.L., Bennett V.C., Kinny P.D., The Itsaq Gneiss Complex of southern West Greenland; the world's most extensive record of early crustal evolution (3900-3600 Ma), „Precambrian Research” 1996, nr 78.

Reich M., ,Pecten” stettinensis v. Koenen, 1868 (Molluska: Bivalvia) aus einer „Stettiner Kugel” (Oligozän) „Geschiebekunde aktuell” 2002, nr 18 (1).

Schidlowski M., Appel P.W.U., Eichmann R., Junge C.E., Carbon isotope geochemistry of the 3.7x109-yr-old Isua sediments, West Greenland: implications for the Archaean carbon and oxygen cycles, „Geochim. Cosmochim. Acta” 1979, nr 43. 
Shields O., Fossil Butterflies and the evolution of Lepidoptera, „Journal of Research on the Lepidoptera" 1976, nr. 15 (3).

Sztajner P., Nagromadzenia fauny w piaskach szczecińskich (oligocen, rupel), poster 2008.

The International Commission on Stratigraphy, 2017, http://www.stratigraphy.org/ICSchart/ChronostratChart2017-02.pdf [dostęp: 27.06.2017].

Wangrin G., Tagfalter-Versteinerung in einer ,,Stettiner Kugel”, „Entomologische Zeitschrift.” 1939, nr 53 (24).

Zawadzki D., Nowak E.B. Cały świat w Muzeum Geologicznym US, „Przegląd Uniwersytecki” 2017, 1-3. 


\section{Dominik Zawadzki}

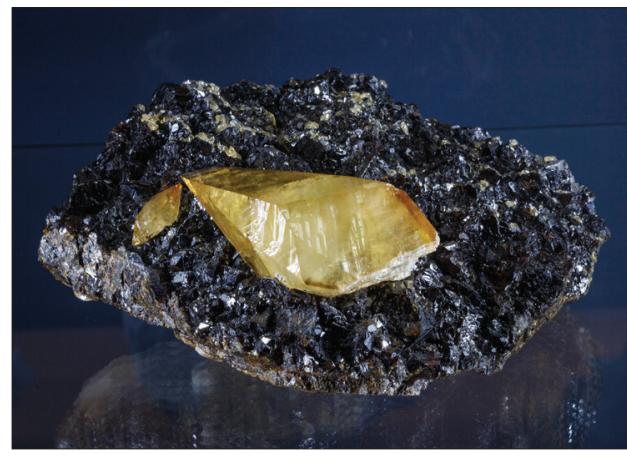

Il. I. Kalcyt na sfalerycie (Cumberland Shaft, Elmwood, Tennessee, USA), nr katalogowy M/773. Fot. F. Kacalski

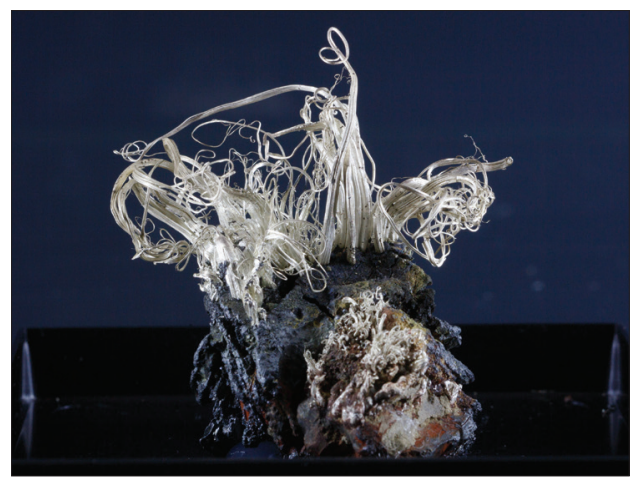

Il. III. Srebro rodzime (Imiter Mine, Ouarzazate Province, Maroko), nr katalogowy M/774. Fot. F. Kacalski

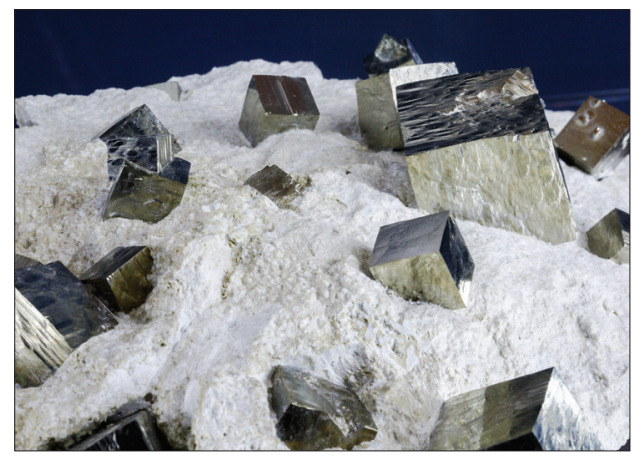

Il. II. Piryt (Navajun, Hiszpania), nr katalogowy M/716. Fot. F. Kacalski

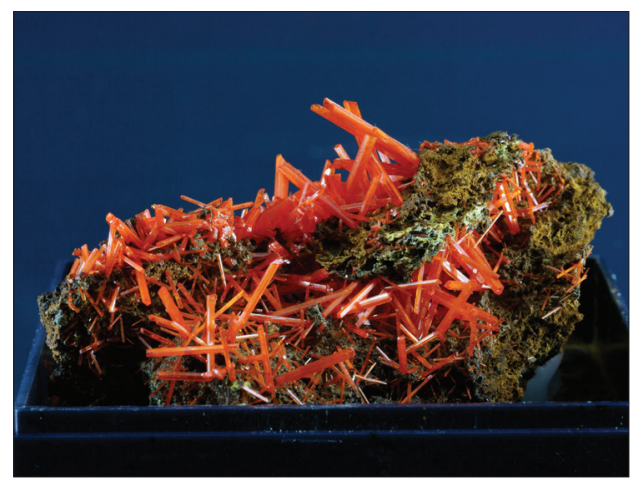

Il. IV. Krokoit (Adelaide Mine, Dundas mineral field, Zeehan District, Tasmania, Australia), nr katalogowy M/776. Fot. F. Kacalski

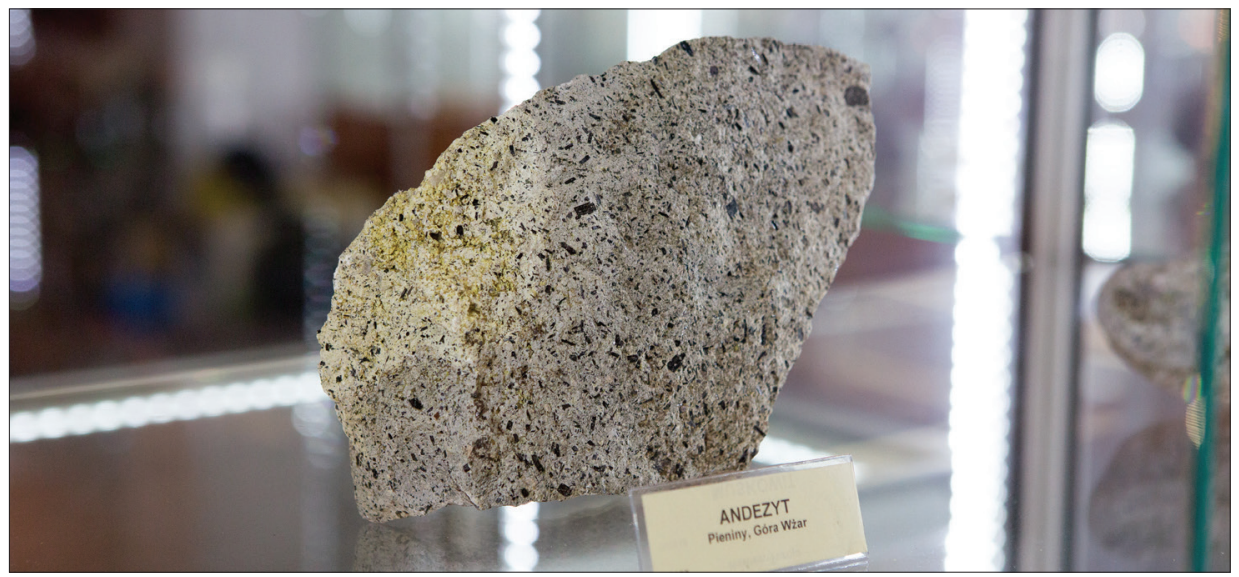

Il. V. Andezyt (Pieniny, Góra Wżar, Polska), nr katalogowy P/0153. Fot. F. Kacalski 


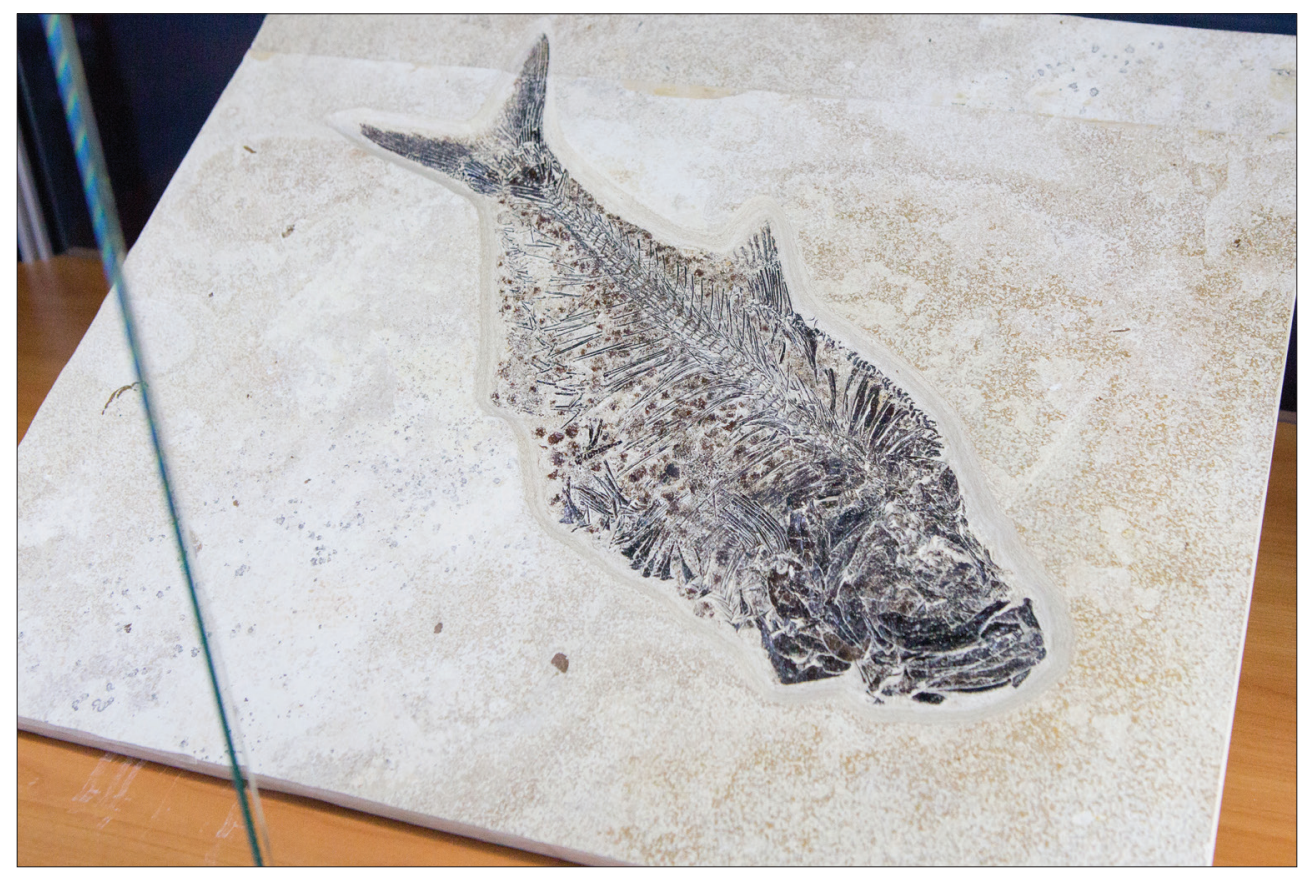

Il. VI. Ryba Diplomystus annalis (Green River Formation, Wyoming, USA), nr katalogowy S/1115. Fot. F. Kacalski

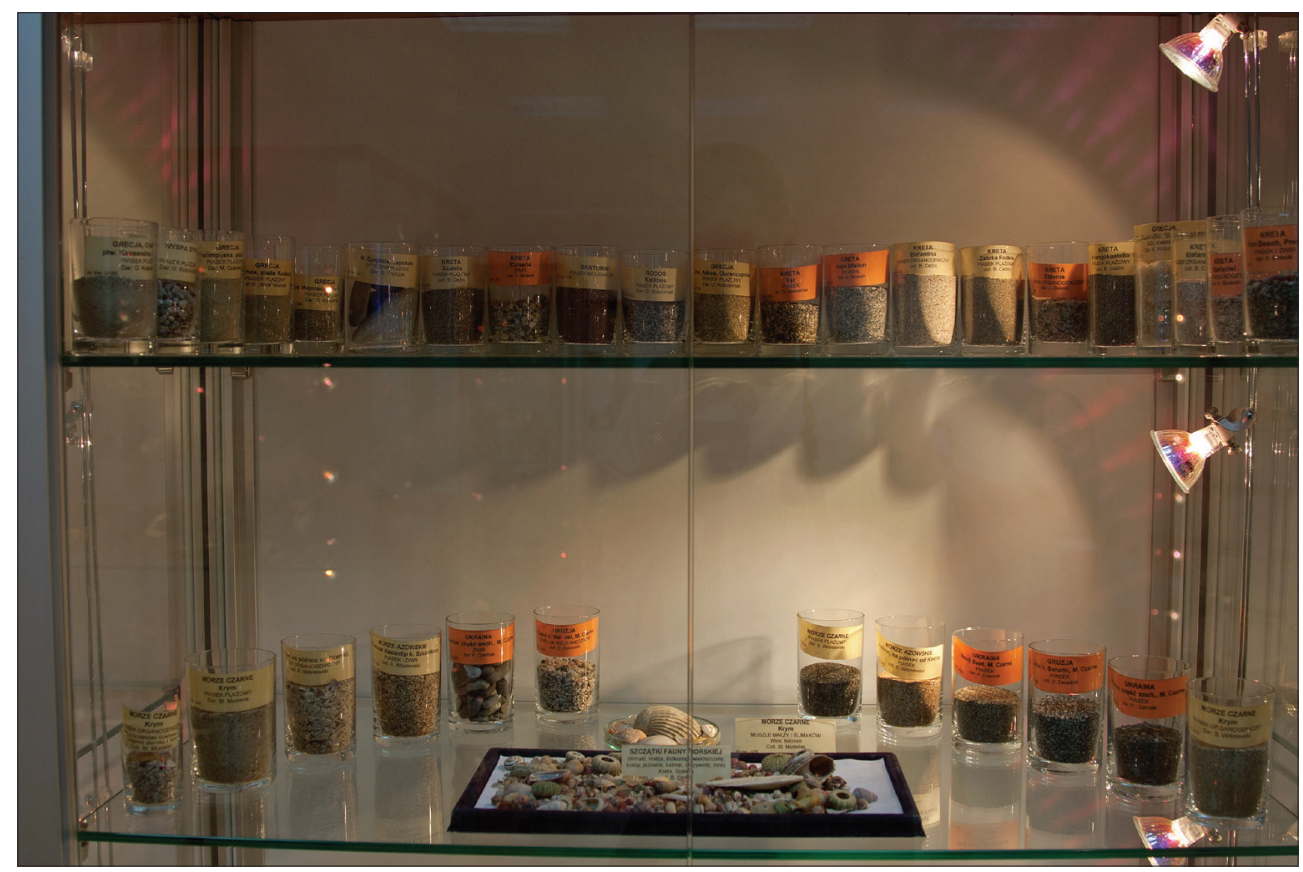

Il. VII. Kolekcja „Piaski świata”. Fot. T. Duda 


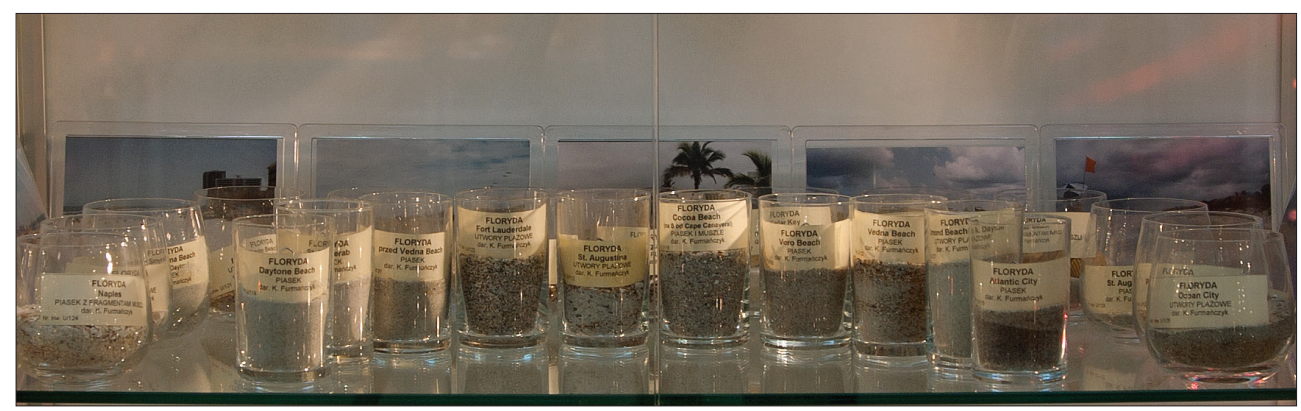

Il. VIII. Kolekcja „Piaski świata”. Fot. T. Duda

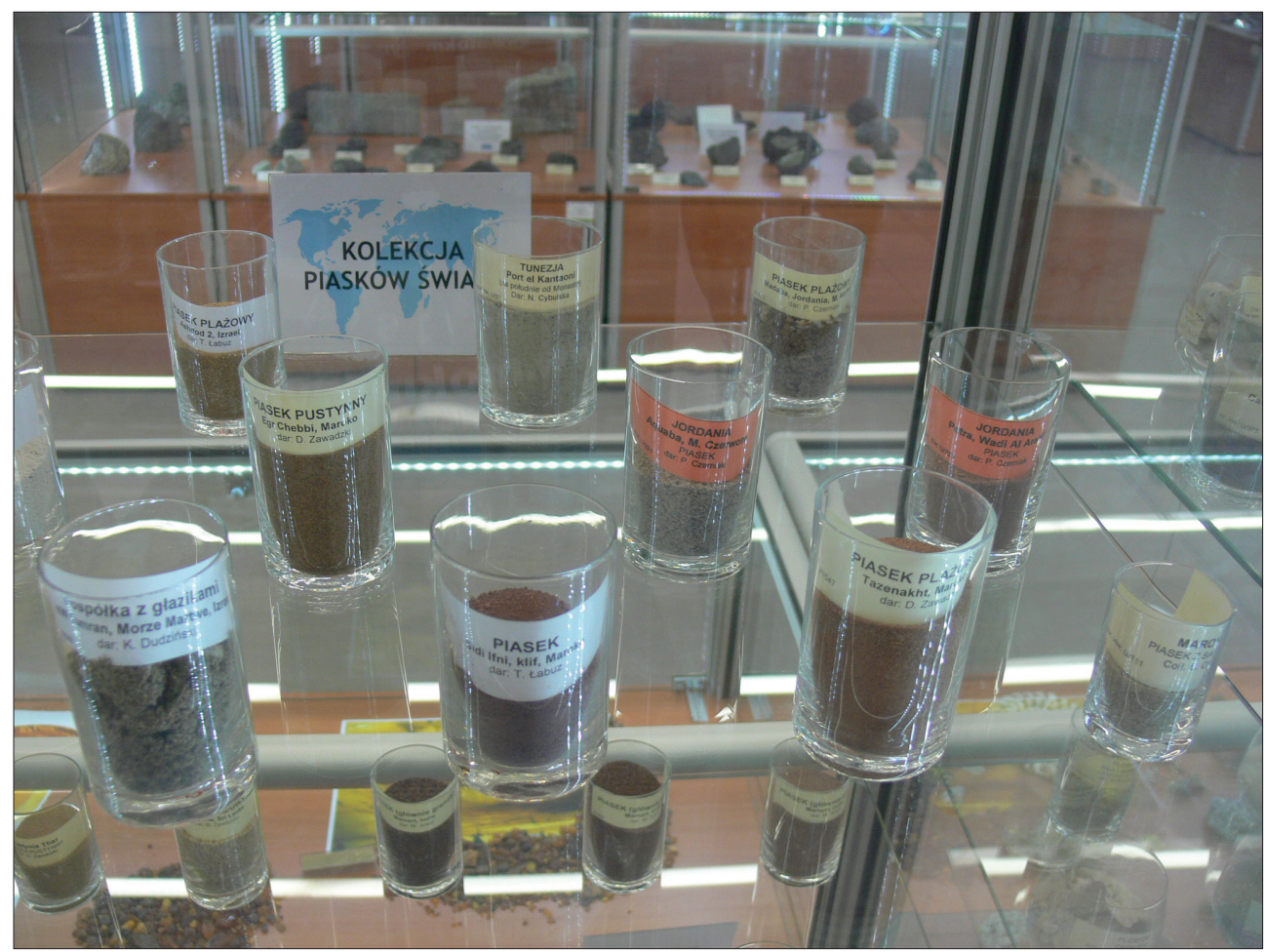

Il. IX. Kolekcja „Piaski świata”. Fot. D. Zawadzki 


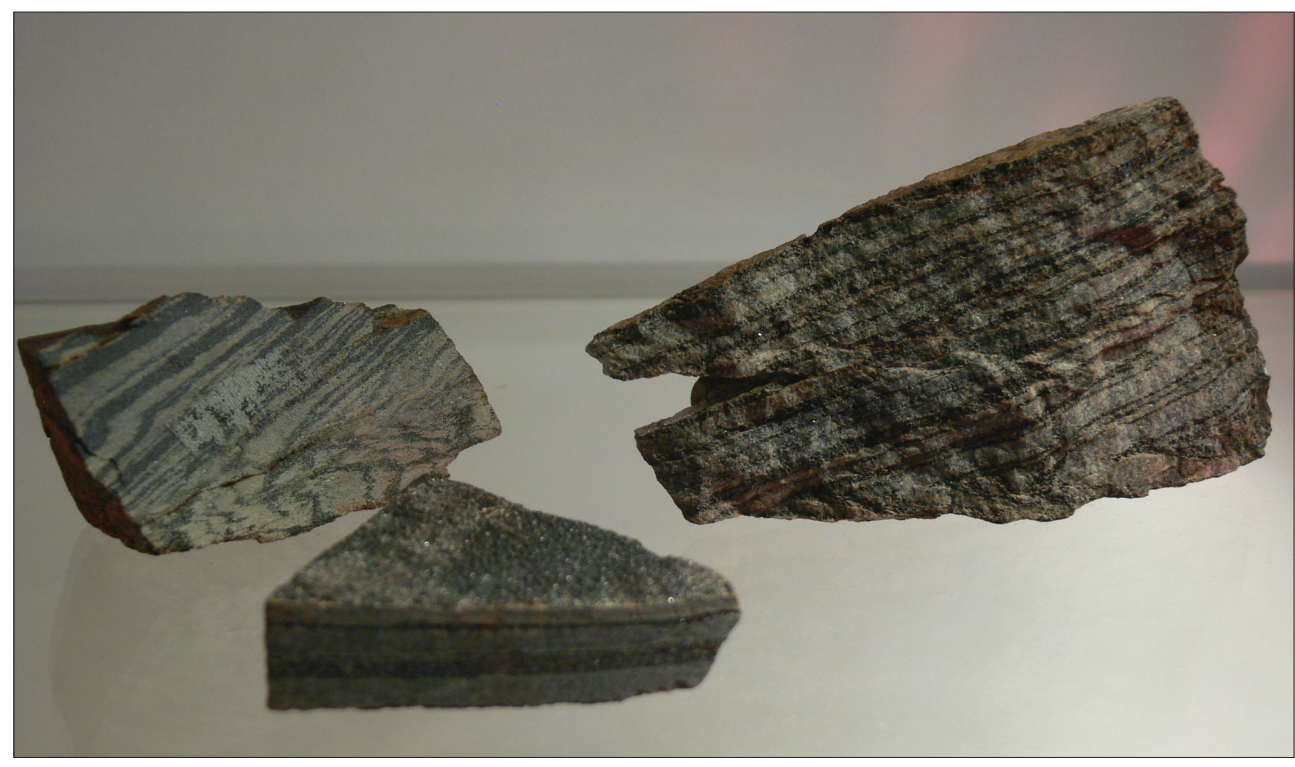

Il. X. Fragmenty jednej z najstarszych skał na świecie liczącej 3,7-3,8 mld lat grenlandzkiej formacji Isua. Fot. D. Zawadzki

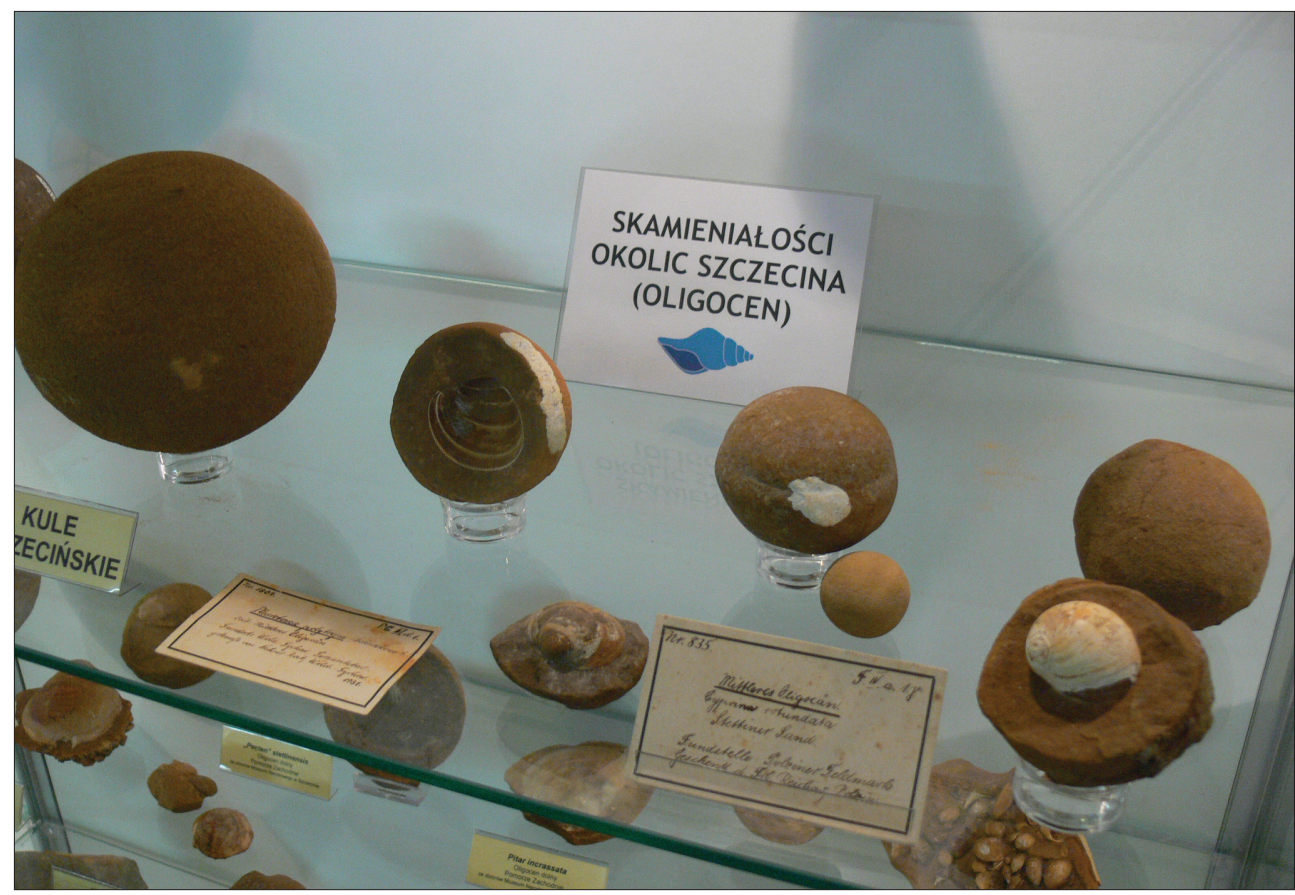

Il. XI. Kule szczecińskie. Widoczne okazy nieprzepołowione oraz rozłupane z odciskami i ośródkami małży i ślimaka. Poniżej historyczne etykietki. Fot. D. Zawadzki 


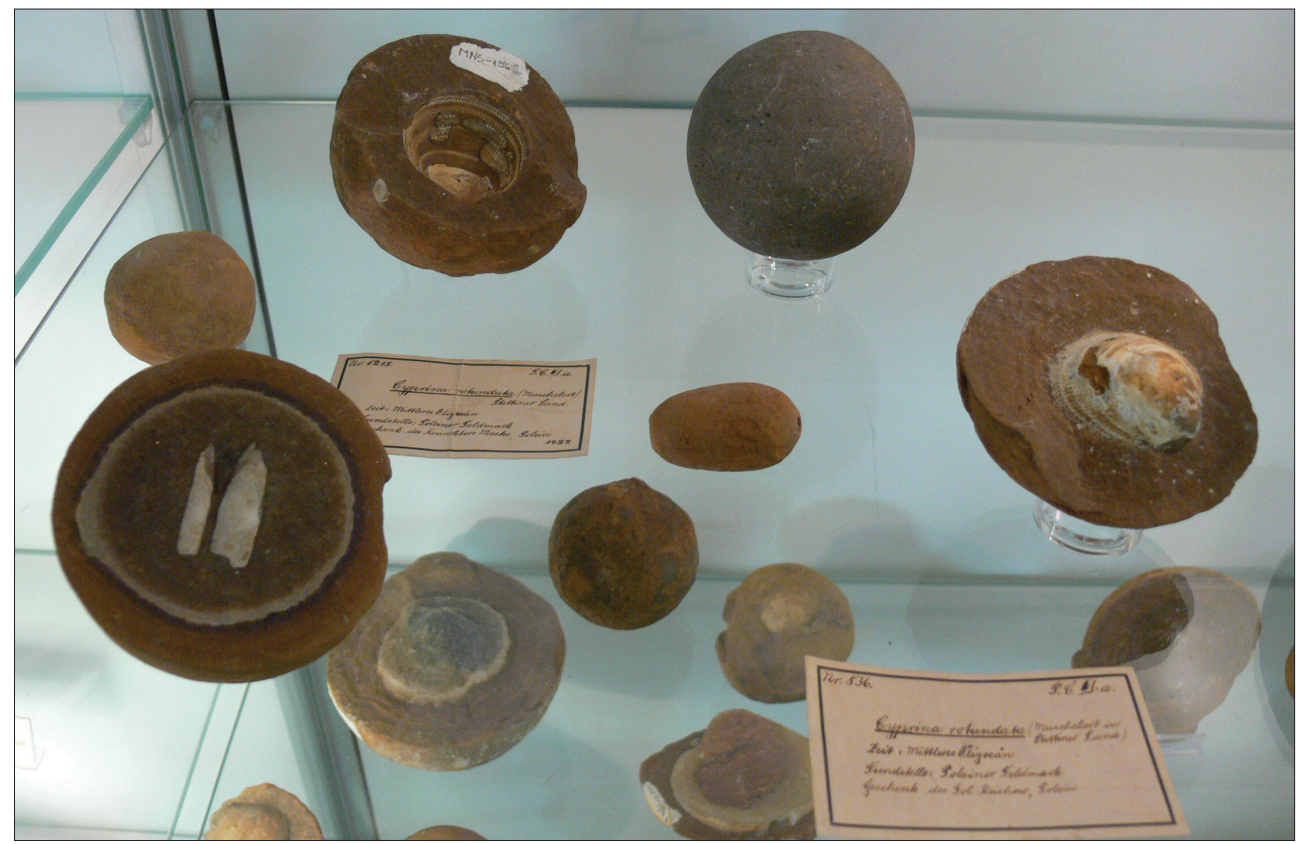

Il. XII. Kule szczecińskie. Widoczne okazy nieprzepołowione oraz rozłupane z odciskami i ośródkami małży. Poniżej historyczne etykietki. Fot. D. Zawadzki

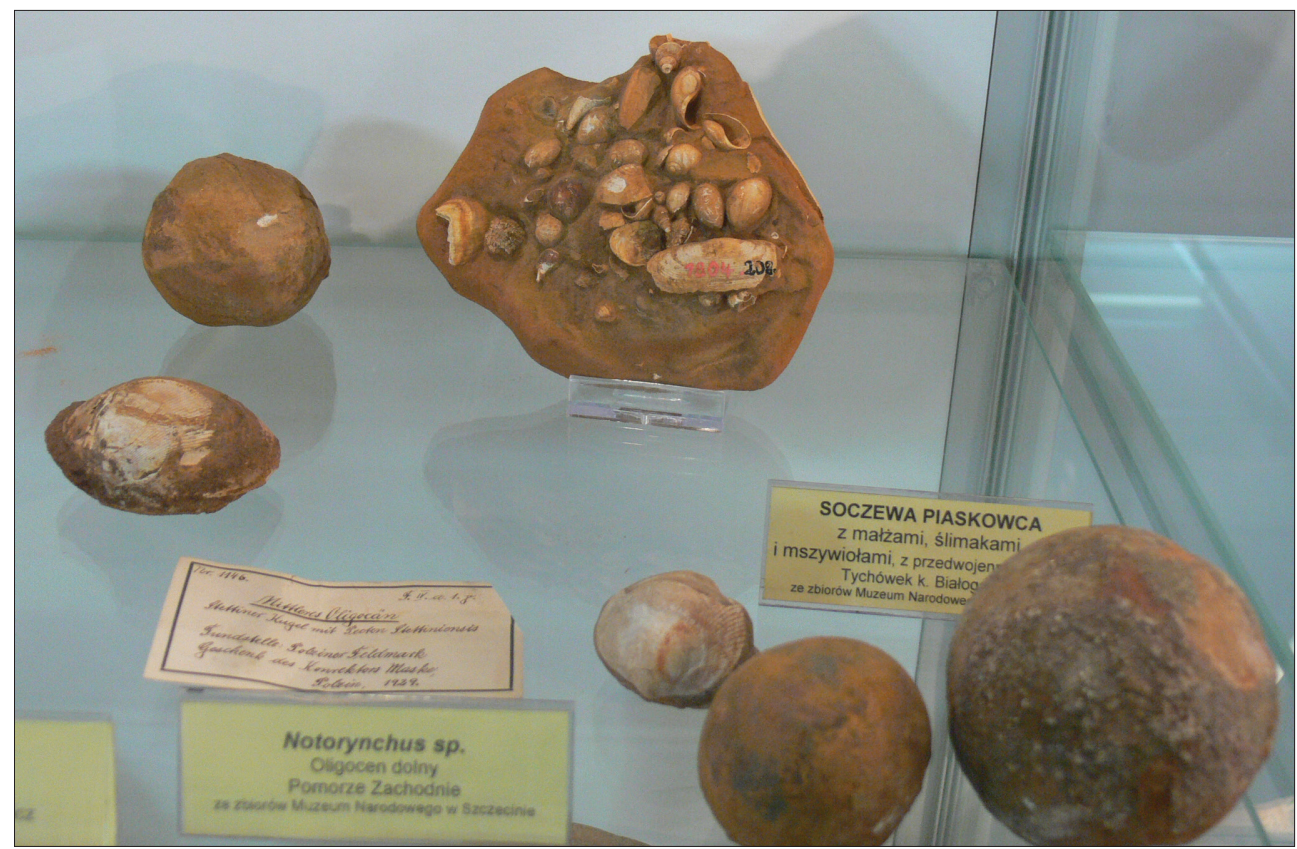

Il. XIII. Kule szczecińskie oraz soczewa piaskowca z dużym nagromadzeniem małży i ślimaków. Widoczne oryginalne numery inwentarzowe nadane na okazie małża. Poniżej historyczne oraz nowe etykietki. Fot. D. Zawadzki 


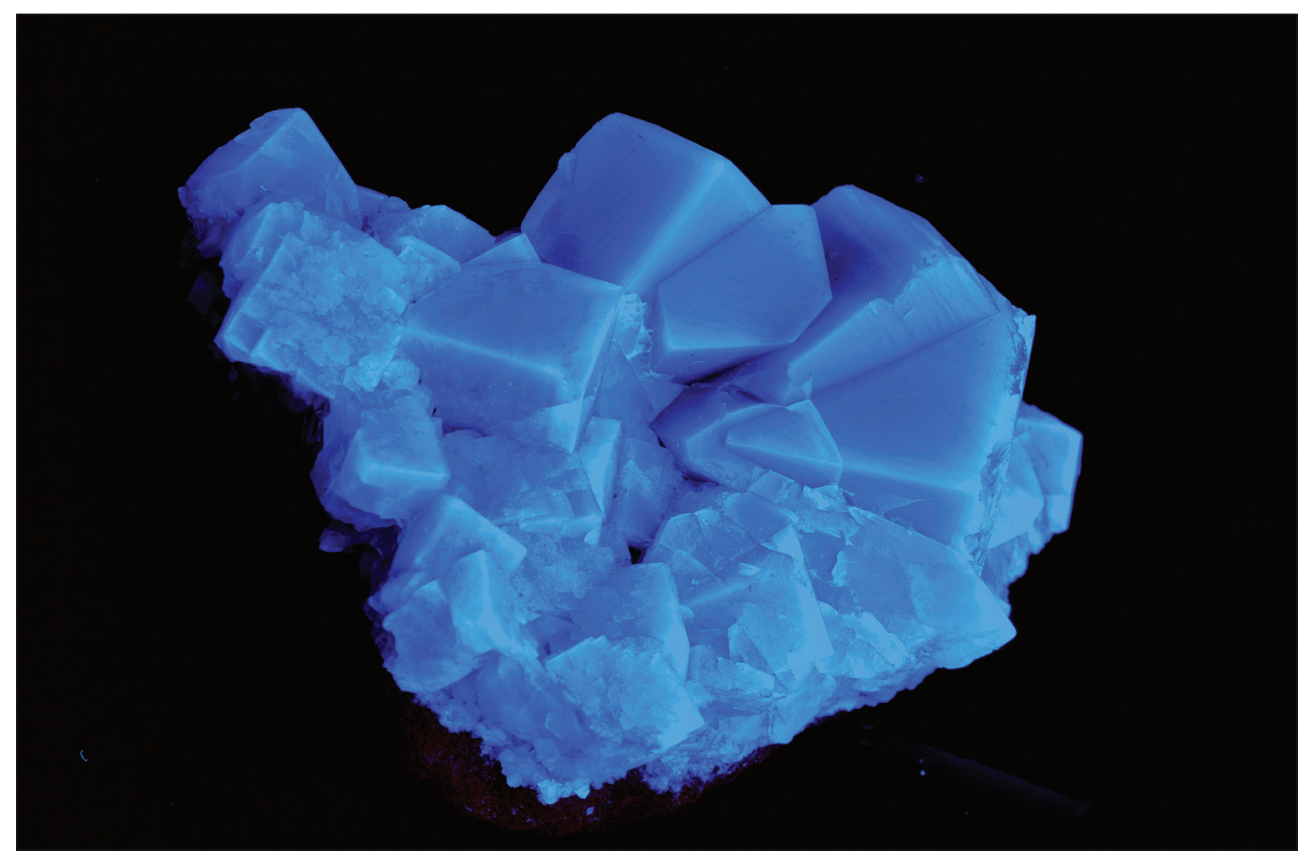

Il. XIV. Fluoryt (Rogerley Mine, Wielka Brytania) (kolekcja prywatna D. Zawadzki). Fot. F. Kacalski.

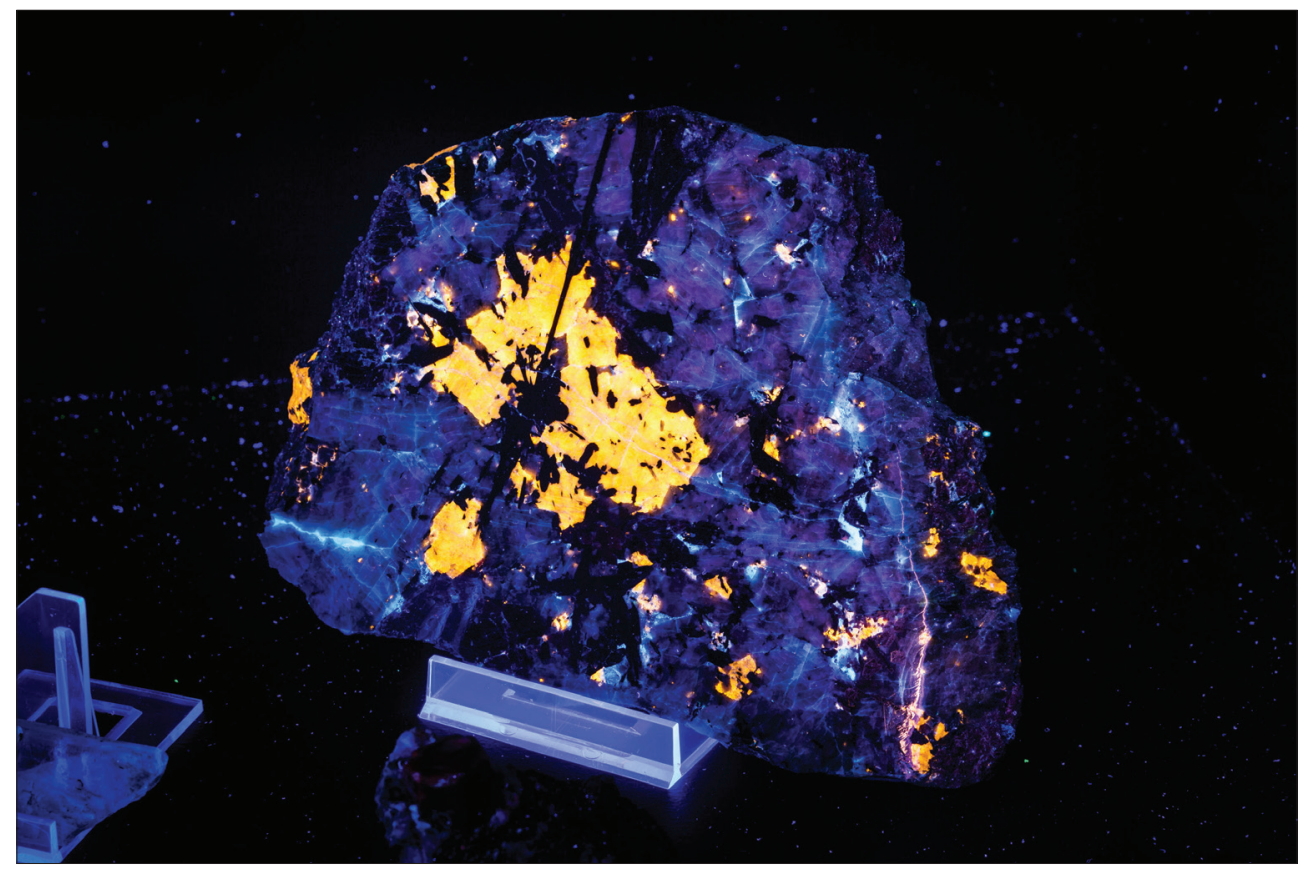

Fot. XV. Apatyt, eudialit, egiryn - płyta polerowana (Chibiny, Półwysep Kolski, Rosja), nr katalogowy M/755. Fot. F. Kacalski 